トピックス 新進気鋭 シリーズ
第50回 日本生物物理学会年会 若手招待講演

\section{$F_{0} F_{1}-A T P$ 合成酵素のプロトン駆動力による 回転運動の直接観察}

渡邊力也 東京大学大学院工学系研究科応用化学専攻

\section{1. はじめに}

$\mathrm{F}_{\mathrm{o}} \mathrm{F}_{1}$-ATP 合成酵素（ $\mathrm{F}_{\mathrm{o}} \mathrm{F}_{1}$ ) は，細胞膜の両側に形成 される “プロトン駆動力”を利用して生理的に重要な ATP を合成する，タンパク質でできたエネルギー変換 素子である ${ }^{1)} . \mathrm{F}_{\mathrm{o}} \mathrm{F}_{1}$ は，その生理的な重要性だけでな く, 電気・化学間のエネルギー変換の過程で, 分子内 の回転運動を伴らモータータンパク質であることか ら，長年，多くの研究者に注目されている． $\mathrm{F}_{0} \mathrm{~F}_{1}$ は2 つの回転分子モータ一から構成される。1つは膜内在 性の $\mathrm{F}_{\mathrm{o}}$ で，プロトンの輸送と共役して回転すること が予想されて扣り，も51つは水溶性の $\mathrm{F}_{1}$ で，ATP の加水分解 / 合成と共役して回転を行ら。ここ10 数 年に渡り， $\mathrm{F}_{0} \mathrm{~F}_{1}$ のエネルギ一変換機構における回転運 動の役割を理解するため，筆者を含む日本のグループ は，回転運動の 1 分子計測を行ってきた. 取扱いのし やすさから 1 分子計測の中心は, $F_{1}$ 部分単独での回 転運動に関するものであり，その作動原理は非常に理 解が進んでいる2),3). しかし，膜内在性の $\mathrm{F}_{\mathrm{o}}$ ならびに $\mathrm{F}_{0} \mathrm{~F}_{1}$ 複合体がプロトン駆動力によって回転する様子 は，最先端の 1 分子計測法をもってしても観察できて いない.すなわち，それらの作動原理の大部分は未解 明であり，プロトン駆動力による回転運動の 1 分子計 測の実現が，この研究分野の最大の課題であった。

\section{2. プロトン駆動力の制御}

プロトン駆動力による膜タンパク質の“動き”を観 察するらえでの最大の技術障壁は，顕微鏡下でプロト ン駆動力を安定的に発生できないことにある。従来, プロトン駆動力を発生する時は，酸性もしくはアルカ リ性に大きく偏った緩衝液の溶液交換によって，脂質 2 重膜の両側にプロトン濃度差を形成していた ${ }^{4)}$ 。こ の手法では，溶液交換による流体力学的な作用によっ て膜が損傷を受けるだけでなく，元来存在する膜の欠 陷箇所からプロトンが流入し，緩衝液の交換後，数秒

程度でプロトン駆動力が消滅してしまう。よって，プ ロトン駆動力を安定的に発生させることは非常に困難 であった。そこで，筆者は $\mathrm{F}_{\mathrm{o}} \mathrm{F}_{1}$ の回転運動を観察す るため，顕微鏡下に脂質 2 重膜を展開し，膜を介した プロトン濃度差をその両側に安定的に形成する実験系 を新規開発した ${ }^{5)}$ 。本実験系では，プロトン駆動力の 安定的な形成のため，2つの工夫を施した（図 1a).

(i) $\mathrm{K}^{+}$チャネル（KcsA）の膜への再構成

(ii) Caged $\mathrm{H}^{+}$を利用したプロトンの供給

（i）に関しては，KcsA を $\mathrm{F}_{0} \mathrm{~F}_{1}$ と共に膜へ再構成する と，膜の電気抵抗が増加することが明らかにされ，す なわち，KcsAの再構成によって膜の欠陷箇所は減少 し，プロトン濃度差を安定的に形成することができ た。 た，(ii）に関しては，UV光の照射によって Caged $\mathrm{H}^{+}$は分解しプロトンを放出する性質を持つた め ${ }^{6}$ ，溶液交換をせずとも光の ON-OFF でプロトン濃 度差を瞬時に形成することが可能になった（図 1b).

\title{
3. $\mathrm{F}_{0} \mathrm{~F}_{1}$ のプロトン駆動回転
}

$\mathrm{F}_{0} \mathrm{~F}_{1}$ のプロトン駆動回転の 1 分子計測のため, 金ナノ 粒子を回転プローブとした回転運動の高速度計測系 ${ }^{7}$

(a)

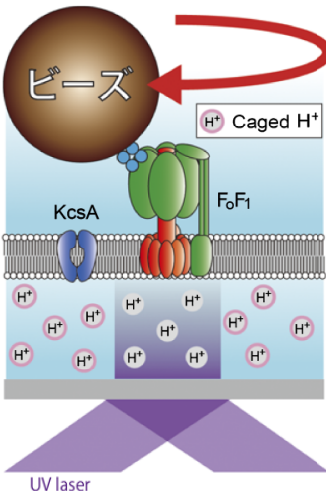

(b)

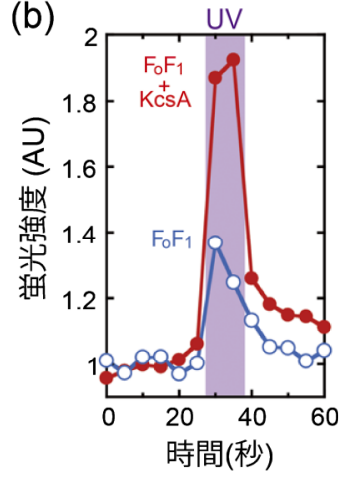

図 1

プロトン駆動回転の 1 分子計測系.（a）計測システムの図, (b) $\mathrm{pH}$ 感受性蛍光色素 (pHrodo) を利用した膜の下側の $\mathrm{pH}$ 変化計測. 酸性条件下で蛍光強度が増大する。

Direct Observation of Proton-driven Rotation of F $F_{1}$-ATP Synthase Rikiya WATANABE

Department of Applied Chemistry, The University of Tokyo

※図 1，図 2 は, 電子ジャーナル（https://www.jstage.jst.go.jp/browse/biophys/-char/ja/）ではカラー版を掲載しています. 
と上述のプロトン駆動力の制御系を組み合わせた実験 系を構築した $\left(\right.$ 図 1a) ${ }^{5}$. この実験系を利用して $\mathrm{F}_{0} \mathrm{~F}_{1}$ の 1 分子観察を行ったところ, プロトン駆動力によっ て時計方向に数 10 回転する様子が確認され，それら はATP 駆動回転とは逆方向の回転であった（図 2a）. 次に，プロトン駆動力の大きさと回転速度の関係を調 ベた。汇同じ大きさのプロトン駆動力を与えたにも 関わらず，回転速度には大きなばらつきが確認された が，最大の回転速度を示すものに関しては，プロトン 駆動力の増加に伴い回転速度が加速することが示され た（図 2b）。ここで，筆者が観察した $\mathrm{F}_{0} \mathrm{~F}_{1}$ の回転運動 とATP の合成反応の共役関係について考察する。先 行研究によって, $F_{1}$ 部分を時計方向に強制回転させ ると 1 回転の間に 3 つの ATP を合成する可能性が示 唆されている ${ }^{8)}$ 。つまり，本研究で確認された回転運 動が ATP の合成反応と強く共役しているのであれば, 回転速度を 3 倍したものが ATP 合成速度に相当する. ここで，回転運動とATP の合成反応が強く共役して いると仮定し，最大回転速度から $\mathrm{F}_{0} \mathrm{~F}_{1}$ の ATP 合成速 度の見積ったところ，多分子計測で得られたATP 合 成速度の実測值 ${ }^{4}$ とほぼ一致することが判明した。 よって，本研究で観察された $\mathrm{F}_{0} \mathrm{~F}_{1}$ の回転運動は，ATP の合成反応と強く共役していたと言える.

\section{4. ステップ回転}

$\mathrm{F}_{0} \mathrm{~F}_{1}$ の回転運動を詳細に解析すると, $120^{\circ}$ 間隔の停 止を伴いながら時計方向・反時計方向に確率的に回転 しており，プロトン駆動力を与えると時計方向への 1 方向性が確認できる（図 2a，挿入図）， $\mathrm{F}_{\mathrm{o}} \mathrm{F}_{1}$ はATP の 合成反応およびプロトンの輸送と回転運動が強く共役 しているため，回転運動の停止は合成反応およびプロ トン輸送に括ける中間体を意味する， $F_{1}$ にはATP 合 (a)

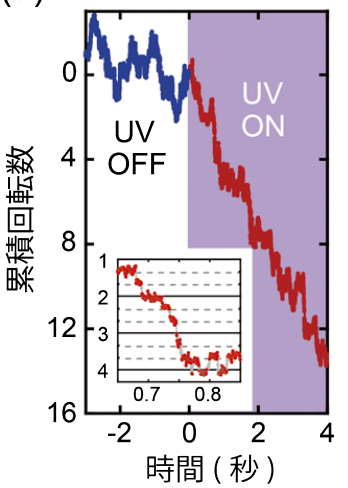

(b)

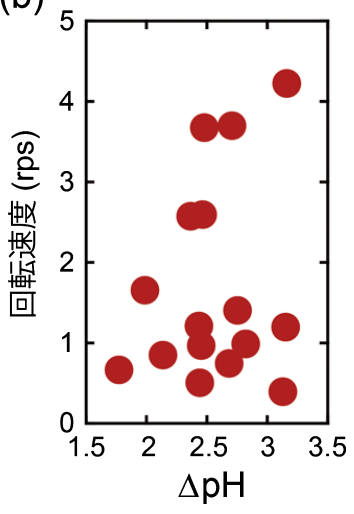

図 2

$\mathrm{F}_{0} \mathrm{~F}_{1}$ のプロトン駆動回転.（a）回転運動の経時変化，（b）時計方 向の回転速度とプロトン濃度差.

成のための触媒部位が 1 分子あたり 3 個存在し ${ }^{9}, \mathrm{~F}_{\mathrm{o}}$ にはプロトンの輸送部位が 10 個存在する ${ }^{10)}$. すなわ ち，本研究で観察された $120^{\circ}$ 間隔の停止を伴った回 転は， $F_{0}$ の 10 回対称性ではなく $F_{1}$ の 3 回対称性を反 映しているため，回転運動の律速過程はATP の合成 反応であると言える. 次に停止時間の解析を行った. プロトン駆動力がない場合，時計方向および反時計方 向の回転直前の停止時間はほぼ同じであった。一方, プロトン駆動力を与えると，時計方向の回転前の停止 時間は短くなり，反時計方向の回転前の停止時間は長 くなった。これは，プロトン駆動力を与えることで， 時計方向に存在するエネルギー障壁の高さが反時計方 向に比べ低くなり非対称になったことを意味する。す なわち，このエネルギー障壁の非対称性が，回転運動 の 1 方向性（時計方向の回転）に寄与していると考兄 られる。

\section{5. おわりに}

筆者は, プロトン駆動力による $\mathrm{F}_{0} \mathrm{~F}_{1}$ の回転運動の 直接観察に成功した。本研究で開発した技術は，今後 $\mathrm{F}_{0} \mathrm{~F}_{1}$ だけでなく，他のイオン駆動力を利用した膜タン パク質などにも広く応用されていくことが期待される.

\section{謝 辞}

本稿で紹介した研究は, 東京大学の野地博行教授, 田端和仁博士，飯野亮太博士，福井大学の老木成稔教 授，岩本真幸博士，中央大学の上野博史博士との共同 研究です。深く感謝いたします。

文 献

1) Junge, W. et al. (2009) Nature 459, 364-370.

2) Noji, H. et al. (1997) Nature 386, 299-302.

3) Watanabe, R. et al. (2010) Nat. Chem. Biol. 6, 814-820.

4) Iino, R. et al. (2009) J. Biol. Chem. 284, 17457-17464.

5) Watanabe, R. et al. (2013) Nat. Commun. 4, 1631.

6) Barth, A. et al. (2002) Biophys. J. 83, 2864-2871.

7) Ueno, H. et al. (2010) Biophys. J. 98, 2014-2023.

8) Rondelez, Y. et al. (2005) Nature 433, 773-777.

9) Abrahams, J.P. et al. (1994) Nature 370, 621-628.

10) Jiang, W. et al. (2001) Proc. Natl. Acad. Sci. USA 98, 4966-4971.

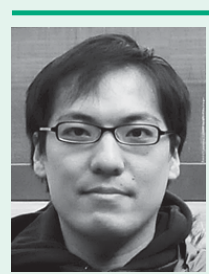

渡邊力也
渡邊力也（わたなべ りきや） 東京大学大学院工学系研究科助教 2009 年大阪大学大学院工学研究科博士課程修了, 博士 (工学)

研究内容:世界最小モー夕一の開発

連絡先: $=113-8656$ 東京都文京区本郷 7-3-1 工学部 1 号館 501 号室

E-mail: wrikiya@nojilab.t.u-tokyo.ac.jp 